\title{
A cidade antiga (La cité antique)
}

Por: Levi Leonel de Souza

Fustel de Coulanges (1830-1889) foi um dos mais célebres historiadores franceses. $L a$ cité antique tornou-se um clássico da investigação histórica, abordando o tema do nascimento da cidades-Estado por meio de extensa documentação que leva o estudioso das leis, o historiador, o linguista, ou o leigo, com competência e segurança, pelo labirinto das instituições jurídicas, familiares e políticas dos dez ou doze séculos em que vigoraram o regime municipal e a religião dos antigos. A meta é ambiciosa, pois pretende colocar-se dentro da cidade antiga sem dar atenção às opiniões e fatos contemporâneos a ele. Produto de um pensamento positivista, em que se crê estar distante do objeto e podendo analisá-lo sem se misturar com ele, o autor se entrega a sua pesquisa crendo-se desapaixonado e livre. Com o correr da obra o vemos tomar o partido da cultura do último terço do séc. XIX, particularmente no último capítulo, quando fala do cristianismo, mas isso não anuvia o céu de suas pesquisas; competente, trabalhador incansável e meticuloso, nos fornece até hoje um dos mais vívidos panoramas do funcionamento das cidades gregas e romanas à época das gens, tribos e cidades-Estado.

Fustel inicia sua obra nos informando dos costumes e pensamentos a respeito da alma, da morte e a importância de se sepultar o corpo segundo extensos rituais e fórmulas pronunciadas para garantir a felicidade eterna ao falecido. As necessidades do morto são escrupulosamente satisfeitas para que este não venha a se tornar alma errante, sofrendo, assombrando e enviando doenças e má sorte à família; a morte os transformava em seres sobrenaturais e os ritos os transformavam em deuses subterrâneos. "À̀s almas humanas divinizadas pela morte, diz Fustel, chamavam os gregos por demônios, ou heróis. Os latinos, por sua vez, as apelidavamlares, manes, gênios". O autor acredita que o sentimento religioso da humanidade grega e romana começou com este culto e, além disso, a própria cidade antiga deveria ser entendida como um dos resultados de seu aperfeiçoamento nos séculos que viriam, pois o fogo sagrado dedicado aos antepassados, morando no centro da casa, passou a localizar-se no centro da cidade. O deus lar era mantido e mantinha a família; se o fogo se extinguia a família toda estava extinta. Assim, seus ritos diários visavam manter ardendo essa chama que era a manifestação dos deuses familiares, seus antepassados, delineando a relação entre os mortos da família e o lar doméstico, a própria expressão do culto aos mortos. Essa religião doméstica tratava de oferecer os ritos aos antepassados de linhagem masculina de uma mesma família, excetuando todas as outras. 
Depois o autor nos conduz para o seio da família, onde a religião a constitui e é seu principal esteio. Havendo uma necessária relação entre seus deuses e o solo, assentavam no chão o símbolo da vida sedentária, o lar, tomando posse de uma parte de terra que já se constitui, por esse ato, em sua propriedade. Em cada casa havia um altar e ao redor dele, toda manhã, ali se reuniam para dirigir ao lar suas orações, hinos, libações, bebidas e alimentos. O casamento foi a primeira instituição estabelecida pela religião doméstica, contudo não comunicava uma família com outra, ou os rituais de duas famílias, porque o direito de realizar os ritos era transmitido de varão para varão. A mulher, ao casar, passava a adorar os antepassados do esposo; a cerimônia de casamento a impedia de adorar os deuses de seu pai e ao mesmo tempo impunha os de outra linhagem masculina. Percebe-se que a crença na divindade dos mortos e os ritos a eles devidos foram o centro da família; se acaso o fogo, que deveria ser ritualizado por um filho, se extinguisse, toda uma legião de mortos e vivos deixariam de extrair dessas relações a vida e seus valores. Por isso o centro das preocupações domésticas era continuar a descendência, proibindo-se o celibato, divorciando-se em caso de esterilidade e mantendo-se a desigualdade entre filho e filha. O direito de propriedade era totalmente privado e fundido à religião doméstica e família. Sua religião prescrevia isolar o domínio e as sepulturas; a tradição ordenava que o lar fosse fixo ao solo e não fosse o túmulo deslocado. "Não foram as leis, mas a religião, aquilo que primeiro garantiu o direito de propriedade", nos diz Fustel. Isso levou, salvo raras exceções, a somente o filho herdar a propriedade (lar e solo), a não existência do testamento e o pátrio poder. Segundo ele a família não recebeu da cidade suas leis, mas sim, da religião. O direito privado teria existido antes da cidade. Ao legislador foi imposta a lei originada na família onde o esposo possuía o poder de senhor do lar, de rei, de magistrado.

As famílias se juntavam em genos (gens em latim) que formavam um grupo com descendência comum e origem pura, com seus deuses comuns, o que, segundo Fustel, não se pode dizer que eram associações de famílias distintas. Usavam o mesmo patronímico vivendo num "verdadeiro corpo, o verdadeiro ser vivo, do qual o indivíduo se tornava apenas membro inseparável; assim o nome patronímico foi o primeiro em data e o primeiro em importância”. A família era um Estado organizado - com seu chefe hereditário - bastando a si própria, explorando a clientela e os escravos, podendo constituir-se de numeroso grupo, com uma religião que lhe mantinha a unidade, por meio do direito privado, leis próprias e formando extensa sociedade. 
$\mathrm{O}$ autor prossegue definindo melhor a cidade antiga, começando pelas fratrias, cúrias e tribos. Com o alargamento das famílias foi necessário conceber uma divindade superior aos deuses domésticos que fosse comum e velasse pela fratria como um todo. $\mathrm{O}$ alargamento das fratrias acabou gerando a tribo com seus altares aos deuses e heróis e um direito mais complexo, não havendo, acima dela, poder social algum. As cidades foram, então, reuniões de tribos que se submetiam ao deus das famílias mais fortes e numerosas; o lar passa a ser apenas o altar de um deus maior e nisso se vê a passagem de estado de fratria ou cúria (latina) para o estado de cidade. Se no começo cada tribo, tal como fora com a família, não se comunicava com outras tribos, a cidade foi o advento de associações de tribos, guardando seus ritos, segredos e identidades. Por exemplo, em Atenas, cada pessoa era ligada a quatro sociedades distintas: a uma família, a uma fratria, a uma tribo e a uma cidade. Eram instâncias que não necessariamente se comunicavam simultaneamente; um homem quando criança pertence à família e anos depois à fratria e assim sucessivamente, até que vinha a ser iniciado no culto público, tornando-se cidadão. Mas cada família mantinha seus cultos, seu altar, seus chefes seus juízes e leis próprias; só em alguns aspectos é que funcionavam como uma cidade única, uma confederação de grupos constituídos antes da formação da cidade. "Cidade e urbe não foram palavras sinônimas no mundo antigo. A cidade era a associação religiosa e política das famílias e das tribos; a urbe, o lugar de reunião, o domicílio e, sobretudo, o santuário desta sociedade. A cidade gerava a urbe e esta era implantada de um só golpe, em um só dia”. [...]“Quando as famílias, as fratrias e as tribos convencionaram unir-se e terem o mesmo culto comum, era fundada a urbe, para representar o santuário desse culto. Assim, a fundação da urbe foi sempre um ato religioso". Escolhida e revelada pela divindade, a localização da urbe se dava com rituais que a assentavam a partir de uma cidade, que ao formar seu corpo de leis e ritos erguiam a urbe. Isto era feito pelofundador, o homem que realizava os ritos religiosos, sem o qual não se estabeleceria a urbe. Ele era o pai da cidade e acabava por ser um deus-lar para a cidade, sendo perpetuado pelo fogo e sacrifícios anuais das vítimas cerimoniais. O governo da cidade estava sob a autoridade religiosa do rei-sacerdote, também seu chefe político. Sua autoridade política vinha de ser sagrado e isso já lhe conferia, por extensão, o poder de magistrado, fato que não surpreende, uma vez que o rei era escolhido entre os paterfamilias os senhores do lar que reinavam absolutos nos tempos das famílias e que, na cidade, representavam a aristocracia.

A lei estava nas mãos dos pontífices que eram considerados os únicos jurisconsultos competentes por causa de sua origem religiosa. E como as leis advieram dos deuses, nada 
mais natural que o direito fosse exercido pelo rei pontífice, que a conhecia de ter sido iniciado por seu pai que, por sua vez ouvira de seu pai, e assim por diante. Também não "bastava habitar a urbe para se estar submetido às suas leis e pelas mesmas protegido; cumpria ser seu cidadão. A lei não existia para o escravo, como também não protegia o estrangeiro" [bem como estes não podiam] "entrar na partilha das coisas sagradas". Ninguém poderia se naturalizar numa cidade se já pertencesse a outra urbe, sendo esta sua pátria - terra pátria. Segundo o autor a religião fazia de cada urbe um corpo, sem possibilidades de associar-se a nenhum outro. O isolamento era a lei da cidade; sua autonomia política, jurídica, governamental, religiosa e moral em relação às outras era seu bem maior. Esse formidável regime municipal, contudo, sempre esteve ameaçado pela resistência interna de clientes e escravos, bem como pelos ataques de outras cidades. Logo foi necessário uma federação de cidades para que se pudesse admitir as novas reivindicações políticas e jurídicas, bem como aplacamento das discórdias e, no limite, a expansão do poder de certas cidades, como Atenas, Esparta e Roma.

$\mathrm{Na}$ última parte de seu livro Fustel se dedica a mostrar o desmonte deste regime municipal por uma série de revoluções que se iniciam pela retirada da autoridade política dos reis, atitude tomada pela aristocracia, constituída de patres -os chefes de família. Em Esparta, Atenas e Roma a realeza foi alvo de constantes ataques da aristocracia - os eupátridas. Em seguida houve alterações na constituição da família, desaparecendo a primogenitura, desagregando as gens, quase sempre nos movimentos que a realeza fez para enfraquecer os iguais - os chefes das gentes. A libertação dos clientes acabou arrancando a terra à religião e entregou-a ao trabalho, já inaugurando o direito à posse, mas não, ainda, o de propriedade. Talvez a revolução mais contundente, pelo menos em extensão, tenha sido a participação da plebe no regime da cidade, colocando no poder os tiranos, chefes que não podiam ser reis, por faltar-lhes os segredos religiosos, inaugurando o poder do homem sobre o homem, com a missão precípua de proteger a plebe contra os ricos. Daí em diante a aristocracia, que não conseguia voltar ao poder, passou a colaborar com as tentativas de se instalar regimes monárquicos, organizando-se em um corpo semelhante a aristocracia e se espalhou por toda a Grécia e Itália (séc. VII ao V a.C.), distinguindo-se em classes apenas pela quantidade de riqueza. Nesse regime cada cidadão podia exercer o sacerdócio por um ano, sem privilégios de nascimento, de religião ou político. Roma foi exceção, onde o patriciado manteve o poder, criando-se o tribunado da plebe - o plebeu tornava-se ele mesmo sagrado para que pudesse legislar sobre a plebe. Esse caráter de sacralidade era transmitido de tribuno a tribuno, tendo sido doado pelos religiosos do patriciado que eram os criadores da sacralidade doravante transmitida. 
O direito tornou-se público e conhecido por todos, sendo do povo a emanação do poder de promulgar leis que o legislador possuía, bem como as leis deixam de ser patrimônio das famílias sagradas. Com isso, surge a revolução democrática, onde qualquer cidadão rico poderia ser, por exemplo, magistrado, e em tese todos podiam alcançar os mais alto degraus sociais sem serem eupátridas ou patrícios. Mas também, por causa das guerras que dizimavam as classes superiores, estas foram obrigadas a oferecer armas e títulos às classes inferiores que acabaram por formar parte importante do povo. Por ser uma democracia onde todos, por direito, exerciam as funções da malha de governo, cedo acabou por desaparecer o regime democrático, sufocado pelo excesso de atribuições do cidadão e do quanto caro isso era para ser mantido. O regime municipal se esvaiu por motivos bem diversificados: as cidades-Estado se uniram, formando federações; filósofos como Pitágoras e Anaxágoras combateram as leis da cidade; os sofistas começaram a falar de uma nova justiça; Sócrates combate a tradição; as idéias de Platão e Aristóteles são contrárias ao regime municipal. Todos foram responsáveis pelo seu enfraquecimento: desde as tímidas investidas de Platão (que adorava o governo da cidade e as tradições) até as fortes posições políticas de Zenão (concebendo a idéia de Estado como composto por todo o gênero humano). Mas quem deu o toque mais profundo e duradouro nestas transformações foram os estoicistas, emancipando o indivíduo, rejeitando a religião da cidade, desdenhando da servidão do cidadão ao Estado, libertando sua consciência, incitando-o a participar da política e estimulando-o a aperfeiçoar-se intimamente (algo inexistente nos regimes anteriores).

\section{O autor e seus contemporâneos}

Ao leitor de Fustel parece que este esteve inteirado das idéias do francês Auguste Comte (1798-1857) e sua obra "Curso de Filosofia Positiva", onde afirma que todos os fenômenos estão sujeitos a leis naturais uniformes; o projeto comtiano era fazer com as ciências sociais o que Galileu, Kepler e Newton fizeram pelas ciências naturais, fundamentando suas teorias nas leis das três etapas: a teológica (onde o homem explica os fenômenos naturais e sociais em termos divinos), a metafísica(onde a explicação está em forças abstratas) e na científica - o positivismo (explicação baseada em leis imutáveis da natureza). Segundo o positivismo, os estudos históricos se atrasaram em relação à física, matemática ou astronomia. É exatamente com essa impressão que ficamos ao ler sua obra. Tanto a de que ele tentou corrigir esse atraso, bem como o de que não foi tão positivista. Assim, o vemos declarar, de modo positivo, a respeito de crença: "Nada de mais poderoso existe sobre a alma. A crença é obra do nosso espírito, mas não encontramos neste liberdade para modificá-la a seu gosto. A 
crença é de nossa criação, mas a ignoramos. É humana, e a julgamos sobrenatural. É efeito do nosso poder e é mais forte do que nós" (139/140). Mas, antes (p. 2,3), disse: “Tentaremos mostrar por que regras eram regidas estas sociedades e deste modo mais facilmente verificaremos por quais razões essa mesmas regras jamais poderão voltar a reger a humanidade". Quando pensamos em condições de produção da sociedade, em termos ideológicos, Fustel nos faz deter o pensamento, dizendo que a "causa que as produz deve ter algo de poderoso, devendo residir no próprio homem, [que] algo do próprio homem se transformou. Temos, efetivamente, algo do nosso ser a modificar-se de século em século: a nossa inteligência”. Mas, para nosso século, a identidade é um movimento na história (E. Orlandi, 1990); a inteligência, o sujeito são precipitados políticos, algo que escapa a Fustel, tanto por tentar atender ao positivismo, quanto por não ser fiel a ele, ficando no estágio metafísico de produção de conhecimento, afirmando que a cidade dos antigos, sua política, sua urbe, suas instituições jurídicas foram produtos da religião, isto é, da crença destes homens. Com isso, ele não parece ter conhecido as idéias de outro contemporâneo, dessa vez alemão: Karl Marx, teórico social, interessado na economia e história (aqui não há novidade, pois Marx só foi reconhecido já no séc. $\mathrm{XX)}$. Se Fustel, brilhantemente, nos mostra a luta de classes em suas entranhas, não parece disposto a dizer, segundo a agenda marxiana, que a história é a história da luta de classes e que seu fundamento é econômico; ou que "cada forma de produção [de riquezas] cria suas próprias relações de direito, formas de governo etc" (1996, p.29), preferindo centrar sua atenção na crença religiosa. Esta é que seria o motor social da família, do genos e depois da cidade-Estado. Ele crê, mais exatamente, que a economia estava a serviço da religião. Por um viés, hoje corrente, por exemplo, na teoria do discurso (Pêcheux, 1995; Orlandi, 2001), sabemos que a história deve ter como referência as condições de produção que a implica num "processo histórico determinado, em última instância, pela própria produção econômica" (Pêcheux, p.190). Termina seu livro dizendo: "Fizemos a história de uma crença. Estabelecese a crença: constitui-se a sociedade humana. Modifica-se a crença: a sociedade atravessa uma série de revoluções. A crença desaparece: a sociedade muda de aspecto. Esta foi a lei dos tempos antigos" (p.451). Talvez Marx dissesse que o verdadeiro objeto de estudos de Fustel deveria ter sido a luta pelo poder econômico. Quando este passou de uma classe a outra a religião tratou de trazê-lo de volta ou novas religiões se fizeram necessárias para administrar essas passagens. Diga-se, também, que Fustel nos brinda com um panorama nítido do nascimento do Direito e suas instituições. Algumas das questões de sua época (que sobrevivem ainda hoje) sobre a origem de certas figuras jurídicas são tratadas com cuidado e de modo 
bastante consequentes. Trata-se, pois, de uma obra que bem pode auxiliar o estudioso das leis antigas.

Sua obra nos impressiona vivamente, pela obstinação em determinar seu objeto de estudos. Talvez se possa dizer de sua obra o que se disse de Marx: que é um clássico a quem nunca se adere integralmente. E se a obra marxiana obriga a releituras, a obra de Fustel, por seu turno, e pelo ofício de historiador, é uma releitura, ela mesma, da história da história.

\section{REFERÊECIAS:}

COMTE, Auguste Curso de filosofia positiva. São Paulo, SP: Nova Cultural, 1996. (Os pensadores).

MARX, Karl Para a crítica da economia política. São Paulo, SP: Nova Cultural, 1996. (Os pensadores).

ORLANDI, Eni Puccinelli Análise de discurso. Campinas, SP: Pontes, 3.ed., 2001. PÊCHEUX, Michel Semântica e discurso. 2.ed. Campinas: Ed. Unicamp, 1995. 